\title{
Inclusive Teaching Practices, Minimizing Violence and Enhancing Learning in the Cameroonian School Melieu
}

\author{
Nicoline Agbor Tabe (Corresponding author) \\ Department of Bilingual Letters \\ Higher Teachers' Training College (HTTC) Bambili \\ University of Bamenda, Cameroon \\ Seino Evangeline Agwa Fomukong \\ Department of English Modern Letters \\ Higher Teachers' Training College (HTTC) Bambili \\ University of Bamenda, Cameroon
}

Received: April 15, 2020 Accepted: May 4, 2020 Published: May 8, 2020

doi:10.5296/ijele.v8i2.16994 URL: https://doi.org/10.5296/ijele.v8i2.16994

\begin{abstract}
This paper investigated Inclusive Teaching Practices by English Language instructors and its role in minimizing violence and enhancing learning in the classroom. Through the use of a questionnaire strategy and using well-known principles of Rogers' client-centred therapy and Inclusive school theory of Mel Ainscow and Tony Booth, data was designed and administered to English language instructors in some three secondary schools (GBHS Bafang, GBHS Bamenda and GTHS Maroua) randomly selected from three regions in Cameroon which had generated discussion on the subject matter. Findings revealed that most English language instructors have never participated in workshops or career development courses on special needs education, inclusive teaching and differentiation and so, have not acquired the competence needed in inclusive teaching. Further findings showed that, most teaching is not inclusive, humanistic and holistic and thus creates tension, frustration, isolation, humiliation and no sense of belonging of students with impairments. Such environment breathes hatred, hate speech and violence. Recommendations have been made to the ministries of Education in Cameroon, teachers' training colleges, school administrators and teachers to redress the situation.
\end{abstract}

Keywords: Inclusion, teaching practices, differentiation, violence classroom, enhancing learning 


\section{Introduction}

The notion of inclusion must be seen as "a fundamental human right of all learners" and "a principle that values the well-being of all students, respects their inherent dignity and autonomy, and acknowledges individuals' requirements and their ability to effectively be included in and contribute to society" (the United Nations, 2006 cited by Renáta et al, 2018:11). The ever demanding need for inclusion and equity to the enhancement of teaching/learning is a persistent theme in recent literature which has been explored by multiple education stakeholders, policymakers and scholars. Ainscow, Booth and Dyson (2006: 295) opine that inclusion has become a global agenda for educational institutions, arguing that all such institutions "should concern themselves with increasing the participation and broad educational achievements of all groups of learners who have historically been marginalized". Inclusive teaching "includes all students, and welcomes and supports them to learn. No-one should be excluded. Every child has a right to inclusive education, including children with disabilities" (UNICEF, 2017). UNESCO (2005) views inclusive teaching as "a dynamic approach of responding positively to pupil diversity and of seeing individual differences not as problems, but as opportunities for enriching learning". Inclusive teaching, according to Beaudoin, (2013:4), "embraces diversity in order to meet the varying learning needs and styles of students. It encompasses a broad range of best teaching practices that, changes the perspective on teaching students from a more reactive teacher-centred approach, to a more proactive student-centred approach. Hockings (2010:1) argues that, "inclusive learning and teaching in higher education refers to the ways in which pedagogy, curricula and assessment are designed to engage students in learning that is meaningful, relevant, and accessible to all". For other researchers (Vukovic, 2012; Lombardi \& Murray, 2011; Milligan, 2010), inclusive teaching engages varying teaching methods, embraces reflective practice and welcoming attitude that provide all students with engaging, challenging and relevant learning activities in a cognitively, emotionally and physically safe and barrier free environment. For students with disabilities, ITP aim at minimizing the consequences of functional limitations and at removing barriers to learning thereby creating accessible learning environment by planning ahead for a variety of learning needs instead of reacting to a few expressed needs (Beaudoin, 2013:4).

Cognizance that educational inclusion is a broader concept that applies to all groups of learners, our focus will be on learners with the bio-psycho-social model of disabilities. This is one of the major groups that remain excluded due to prevailing social, cultural, and attitudinal barriers. As this study is concerned, Inclusive Teaching (IT) aim at minimizing the consequences of functional limitations and at removing barriers to learning thereby creating accessible learning environment by planning ahead for a variety of learning needs instead of reacting to a few expressed needs. It equally embraces reflective practices, welcoming attitude, adopt appropriate learning activities in affective, cognitive, emotional and physical safe and barrier free environment. Violence in this study can be physical (through assaults), verbal (through hate speech and negative feedback) and emotional (through exclusion).

The role of instructors in quality inclusive education which this paper tackles has been delved into by classroom-based scholars (Savolainen,2009; Sanders \& Horn, 1997; Bailleul et al., 
2008) who asset that the quality of the instructor contributes more to learners' achievement than any other factor, including class size, class composition, or background. It is in line with the above view that Florian \& Rouse (2009: 596) state "the task of initial teacher education is to prepare people to enter a profession which accepts individual and collective responsibility for improving the learning and participation of all children". Also, the need for quality teachers equipped to meet the needs of all learners is evident in providing equal opportunities for all and education for an inclusive classroom community. Reynolds (2009) collaborates the role of teachers in creating a suitable learning setting for inclusive teaching by attesting that, teachers' knowledge, beliefs and values have a bearing in creating effective learning environment for pupils, making the teacher influential in Inclusive Teaching Practices (ITP). Cardona (2009: 35) holds that, focusing on teachers' education “... seem to provide the best means to create a new generation of teachers who will ensure the successful implementation of inclusive policies and practices". That is why Carroll et al., (2003) note that, teachers need confidence in their ability and the knowledge and skills in inclusive education to meet the challenges they will encounter in the present school climate.

In the international scene, the concept of widening participation in education through ITP have been examined by many classroom-based researchers who have discussed its importance (Hatfield, 2003; Hindes \& Mather, 2007) in creating classroom community and employing pedagogical approaches that value, respect, and work for a wide variety of learners (Ouellett, 2005). Also, much research has focused on inclusive teaching and learning for students with disabilities (Fuller, Bradley \& Healey, 2004; Burgstahler \& Cory, 2009). Attention has also been given on ways in which teaching and learning intersect with ethnicity and status (Devlin, Kift, Nelson, Smith, \& McKay, 2012; Ladson-Billings, 2014). In the local Cameroonian context, inclusive teaching has not been given enough attention by researchers, teachers and institutions. There are policy documents on special needs education and inclusive teaching by the state which is not translated to teachers' education, training and teaching practices in the country. This gap gives credence to this current paper which focuses on ITP by English Language instructors (ELI) in Cameroon and its role in enhancing learning and minimizing violence in the school milieu.

The constant increase in violence perpetrated by students on students, students on teachers and teachers on students in the school milieu and more especially in the classroom setting today in Cameroon has left no one indifferent. The violence from student to teachers reached fever peak when a mathematics teacher was stabbed to death by a student in class in GBHS Essos, Yaounde led to an industrial strike action by teachers of secondary education. The Head of State, ministers of education, teachers, students, politicians and media houses strongly condemn such violence. Various meetings, interviews and debates have been organized in the ministries, schools, and media houses like Equinox, Canal 2, and CRTV etc to talk about it and to condemn the act. While some blame the teachers, students and parents, others blame the educational system put in place by the government. However, none of these debates actually provided quick pedagogic solutions to arrest the crisis situation in the classroom. As instructors and researchers what are we doing to provide a collective solution to minimize violence in the classroom milieu? What is the cause of such behaviour in the 
classroom? And how can instructors manage their classes in such a way that violence can be minimized? It is in the light of the above problem that this study investigated Inclusive Teaching Practices (ITP) by English Language instructors (ELI) in some three secondary schools (GBHS Bafang, GBHS Bamenda and GTHS Maroua) randomly selected from three regions in Cameroon and its role in enhancing learning and minimizing violence in the language classroom.

This paper investigates the use of ITP by ELI as a possible way to minimize violence and enhance learning in the classroom. It is broken down into objectives: It investigates ELI competence in ITP, It scales how often ELI adopts ITP and inquires from ELI if ITP can minimize violence and enhance learning in the classroom. Following the above objectives, this paper will be attempting answers as to whether ELI are equipped with skills relevant in ITP, the frequency of ITP adaption in classroom and the impact of ITP in enhancing learning and minimize violence in a language classroom. In accordance with the objectives and research questions, this paper is predicted on the premise that ELI are not fully equipped with skills relevant in ITP and consequently, do not frequently use ITP. ELI incompetence in employing ITP that are humanistic and holistic hampers learning and accentuates violence in class.

This paper is partitioned into four main portions namely; introduction, methodology, results and discussion and conclusion. While the introductory part review of literature, stated the problem, aim, research questions and hypothesis; the subsequent section focuses on the methodology adopted for the study.

\section{Methodology}

This section states the research design, site and population of the study, sampling techniques and data collection tools. This research was based on a survey research design as group of people (ELTs) and items are studied by collecting and analyzing data from a few people and items considered being representative of the whole group.

The chosen sites for the study were three regions of Cameroon: Far North, Northwest and West Regions and population was ELIs. Participants for this study were 26 ELIs with 08 from GBHS Bafang in the West region, 08 from GBHS Bamenda in the Northwest region and 10 from GTHS Maroua in the Far North region. Stratified random sampling technique was used in selecting participants. They constituted 7 male and 12 female teachers with at least five years of teaching experience. The discrepancy in number between sex was based on the fact that the number of female ELI more than double that of the males in the respective schools and in the country in general. In terms of educational level, the teachers where holders of at least the BA degree both trained and untrained.

As tool for data collection is concerned, a questionnaire was designed for ELI and administered to the population stated above. The questionnaire constituted three parts. While part one had to do with identification of informants, part two constituted 18 Yes/No questions intended to find out if ELI are trained in ITP, if they can identify students with deficit in their 
classes and if ITP can minimize violence and enhance teaching in a language classroom. Part three had 24 statements that gave instructors the opportunity to indicate the extent of their agreement or disagreement by scaling their ITP based on their actual experience of teaching English at the moment. The response scale for instructors to choose ranges from 5-1 standing for Always, Usually, Sometimes, Seldom and Never respectively.

Client-centred therapy and inclusive school theory by Rogers and Mel Ainscow and Tony Booth respectively serve as theoretical frame for this paper. The intensification of creating conducive climate in educational settings based on well-known principles of Rogers' client-centred therapy reframing concepts like inclusion, empathy, congruence, and positive regard and bio-psycho-social model of disability were considered. He extended these ideologies, later to education which then have been put to use in a number of educational settings and proved successful measured variables; self concept of students, academic performance, altruism, creativity and fewer acts of vandalism (Crenshaw \& Mordock, 2005; Hoffman, 2000; O’Ferrall, Green \& Hanna, 2010; Rogers, 1983). The said theories inspire the designing of the questionnaire and discussion of the data collected. The forthcoming section presents the results from the questionnaire and generates discussion from them.

\section{Results and Discussion}

Results and discussion are based on data collected using the questionnaire instrument administered to some 26 ELI from GBHS Bafang, GBHS Bamenda and GTHS Maroua. It has been partitioned into three main sections namely: teachers' knowledge of inclusive education and differentiation, the role of ITP in enhancing learning and minimizing violence, teachers' cognitive awareness of the existence of different category of impaired students in classroom and affective inclusive practices adopted by instructors to include all learners during teaching.

\subsection{Instructors' Knowledge of Special Need Education, Inclusive Teaching and Differentiation}

For instructors to adopt ITP, they should know and think about learners and include them in class activities. By doing so, they should be able to identify different category of learners, learning preference in terms of style and deficit in their classes so as to include them or think about them while preparing lessons, instructional material and teaching. This explains why part two of the questionnaire intended to investigate teachers' knowledge of inclusive teaching, differentiation and awareness of the existence of students with deficit in their classes. It constituted 18 Yes or No questions which investigated instructors' participation in inclusive teaching workshops and differentiation workshop and their opinion about the role of inclusive teaching in minimizing violence in the classroom. The results are presented and examined below in turns.

3.1.1 Instructors' Participation in Special Needs Education, Inclusive Teaching and Differentiation Workshops/Courses 
Question 1, 2 and 3 of the instructors' questionnaire investigated if instructors have ever participated in workshops on special needs education, inclusive teaching and differentiation. The results are presented in tables 1, 2 and 3 below:

Table 1. Instructors' participation in workshop/course on special needs education

\begin{tabular}{|l|l|l|l|}
\hline $\begin{array}{l}\text { Instructors in } \\
\text { workshop/course on special need education }\end{array}$ & Total & Yes & No \\
\hline GBHS Bafang & 08 & 00 & 08 \\
\hline GBHS Bamenda & 08 & 05 & 03 \\
\hline GTHS Maroua & 10 & 01 & 09 \\
\hline Total \% & $26(100 \%)$ & $06(23.08 \%)$ & $20(76.92 \%)$ \\
\hline
\end{tabular}

Table 1 shows that in GBHS Bafang, no ELI out of the 08 has ever participated in a workshop/course on special needs education. In GBHS Bamenda and GTHS Maroua, 03 out of 08 instructors and 09 out of 10 instructors respectively have never taken part in the above workshop. In terms of percentages, $76.92 \%$ of instructors have never participated in any course on special needs education while only $23.08 \%$ attested their participation in such workshop. This means that they are not prepared to meet learners with deficits in their English language classes talk less of including them during teaching.

Table 2 below presents results based on instructors' participation in workshop/course on inclusive education.

Table 2. Instructors' participation in workshop/course on inclusive education

\begin{tabular}{|l|l|l|l|}
\hline $\begin{array}{l}\text { Instructors participation in } \\
\text { workshop/course on inclusive education }\end{array}$ & Total & Yes & No \\
\hline GBHS Bafang & 08 & 00 & 08 \\
\hline GBHS Bamenda & 08 & 06 & 02 \\
\hline GTHS Maroua & 10 & 02 & 08 \\
\hline Total \% & $26(100 \%)$ & $08(30.77 \%)$ & $18(69.23 \%)$ \\
\hline
\end{tabular}

Results show that only $08(30.77 \%)$ out of 26 ELIs have participated in workshops on inclusive education while a majority of 18(69.23\%) have never done so. Out of the participants, 06 came from GBHS Bamenda, 02 came from GTHS Maroua and non from GBHS Bafang. The fact that majority of the instructors have never participated in such a workshop is an indicator that the target instructors will exercise lack of knowledge in dealing with students with impairments and thereby not developing the character trait competency needed in inclusive teaching to students. Consequently, instructors will hardly develop awareness of the needs of such category of learners and will be abandoned to themselves because the instructor will hardly think of them while planning lessons, designing material for class activities, assessments and teaching.

Differentiation according to Tomlinson $(2004,2005)$ is a philosophy of teaching that is based 
on the premise that students learn best when their teachers adjust their instruction according to the difference in student readiness levels, interests and learning profiles with the main objective of maximizing every student's ability to learn adopted material based on the needs of students in the classroom. Differentiation practices in a language classroom shows consideration and inclusion to students with various deficits and this competence is acquired most of the time through workshops or career development courses. Differentiate instruction is no longer an option; it is a necessity (Renáta et al, 2018). Teachers' were asked if they have ever participated in any differentiation workshop or course. Table 3 beneath presents the results.

Table 3. Instructors' participation in workshop/course on differentiation

\begin{tabular}{|l|l|l|l|}
\hline $\begin{array}{l}\text { Instructors participation in } \\
\text { workshop/course on differentiation }\end{array}$ & Total & Yes & No \\
\hline GBHS Bafang & 08 & 00 & 08 \\
\hline GBHS Bamenda & 08 & 00 & 08 \\
\hline GTHS Maroua & 10 & 00 & 10 \\
\hline Total \% & $26(100 \%)$ & $00(00 \%)$ & $26(100 \%)$ \\
\hline
\end{tabular}

The above results from question 3 of the questionnaire show that teachers of the target schools have never participated in differentiation workshop. Teachers' zero participation on differentiation workshop shows that instructors will exercise lack of competence in varying classroom tasks with different categories of students with deficit while teaching thereby excluding them in the teaching/ learning process. This means that, teaching practices in the target schools are traditional and outdated since it suits the 'average' student and promotes discrimination against students who require alternative pedagogical approaches to succeed at school.

\subsubsection{Instructors' Understanding of Impairment}

Question 4 and 5 of the questionnaire based on a Yes or No, investigated instructors' understanding of what is the meaning of being impaired. While question 4 had the wrong answer (to be impaired means to be disabled), question 5 had the correct answer (to be impaired means to be rendered less effective). Table 4 forthcoming presents the results.

Table 4. Instructors understanding of impairment

\begin{tabular}{|l|l|l|l|}
\hline $\begin{array}{l}\text { Instructors understanding of } \\
\text { impairment }\end{array}$ & Total & Disabled & $\begin{array}{l}\text { Less } \\
\text { effective }\end{array}$ \\
\hline GBHS Bafang & 08 & 03 & 05 \\
\hline GBHS Bamenda & 08 & 01 & 07 \\
\hline GTHS Maroua & 10 & 06 & 04 \\
\hline Total \% & $26(100 \%)$ & $10(38.46 \%)$ & $16(61.54 \%)$ \\
\hline
\end{tabular}


Results show that in GBHS Bafang 03 out of 08 said to be impaired means to be disabled while 05 said to be impaired means to be rendered less effective. In GBHS Bamenda, 01 out of 08 said to be impaired means to be disabled while 07 said to be impaired means to be rendered less effective. In GTHS Maroua, 06 out of 10 said to be impaired means to be disabled while 04 said to be impaired means to be rendered less effective. The responses given by the instructors point to the fact that a handful of teachers think that to be impaired means to be disabled and thus will never think of learners with minor deficits and thus exclude them while planning their lessons and during teaching.

\subsubsection{Instructors' Awareness of the Existence of Students with Impairment in their Classroom}

For instructors to know and think about learners in class, they should be able to identify learners' deficit in their classes so as to include them or think about them while preparing lessons, designing instructional material, teaching and assessing learners. This explains why question 6 inquired from language instructors if they have ever taught students with impairment before. In GBHS Bafang, all 08 instructors said yes while in GBHS Bamenda, 06 out of 08 said yes and in GTHS Maroua, 04 teachers out of 10 said yes. Looking at the responses of instructors, it is evident that some of them do not know that there exist learners with impairment in all classes. Such categories of instructors are those who think that impairment deals only with extreme situations of blind, dump, deaf and lame. As such, they do not know how to identify learners with minor deficit, make no effort to know them and thus exclude or ignore such learners during their classes.

\subsubsection{Instructors' Identification of Learners with Deficit in Class}

Between 9 and $11 \%$ of students enrolled in University have a disability attested by US and Canadian Sources, such as Statistics Canada. Among those students, two-thirds have a non-visible disability and are more likely to face less favourable attitudes from their educators, such as stereotyping or questioning the authenticity of their disability, therefore making it difficult for them to be accommodated in the schools (Vukovic, 2012, Denhart, 2008, Hindes \& Mather, 2007, Burgstahler \& Doe, 2006, Lehmann, Davies, \& Laurin, 2000). Question 7 to 14 of part two of the questionnaire asked informants to confirm or refute the existence of learners with various deficits in their current language classes. The results have been illustrated below.

Table 5. Instructors' identification of learners with deficits

\begin{tabular}{|l|l|l|l|}
\hline $\begin{array}{l}\text { Instructors identification of learners with } \\
\text { deficit in class }\end{array}$ & $\begin{array}{l}\text { Number of } \\
\text { questions }\end{array}$ & Yes & No \\
\hline GBHS Bafang & 64 & 44 & 20 \\
\hline GBHS Bamenda & 64 & 59 & 05 \\
\hline GTHS Maroua & 80 & 42 & 38 \\
\hline Total & 208 & 145 & 63 \\
\hline$\%$ & $100 \%$ & $69.70 \%$ & $30.30 \%$ \\
\hline
\end{tabular}




\section{Ml Macrothink}

To get the total number of responses by instructors, the number of questions ( 7 to $14=8$ ) was multiplied by the number of informants to get the total per school. Findings show that $69.70 \%$ of the instructors identified various types of learners with impairment in their language classes. Figure 1 below captures the situation.

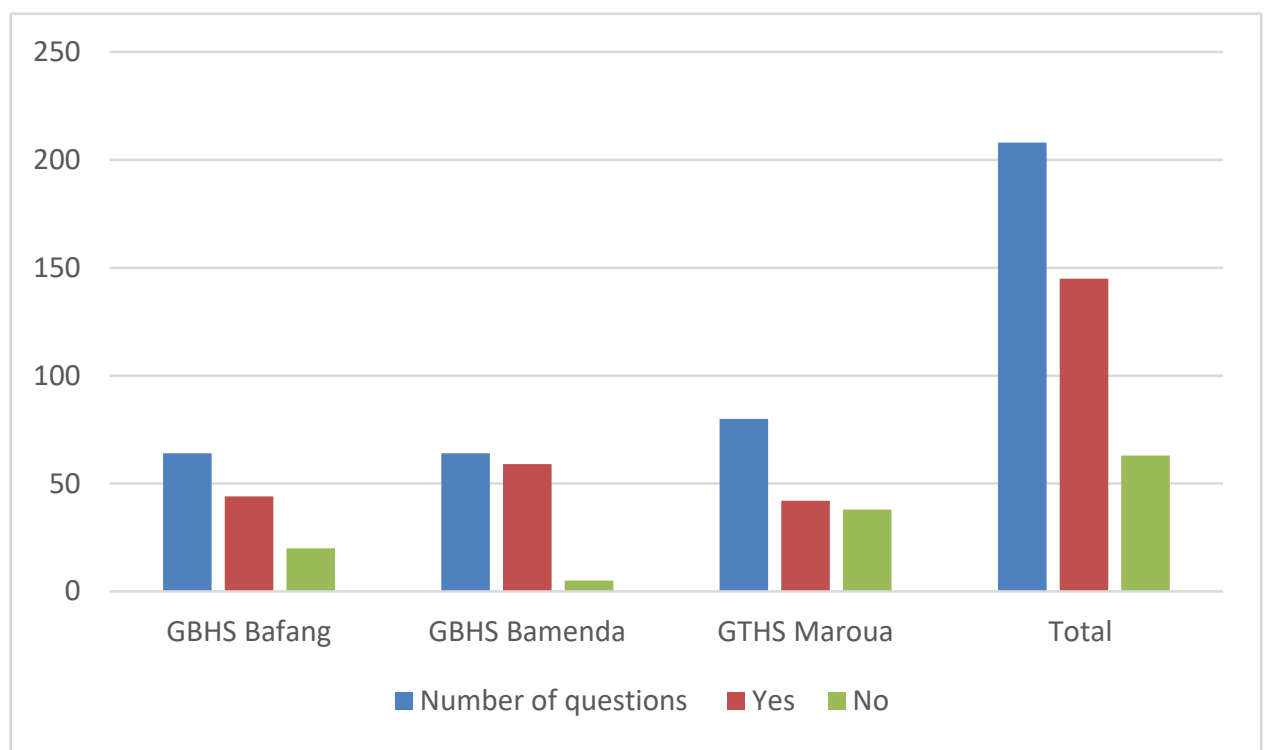

Figure 1. Instructors' awareness of the existence of learners with various deficits in class

The fact that majority of students in language classes suffer from one deficit to another as indicated by the chart above, then, instructors training or courses on special needs education, inclusive teaching and differentiation become paramount to our Cameroonian language instructors for teaching to be inclusive, humanistic and holistic. Research (Beaudoin 2013, Vukovic 2012; Belch, 2011,2004; Wolf, Schreiber, \& Wasserstein, 2008; Burgstahler \& Cory, 2008; Weyandt \& DuPaul, 2006) has proven that many students have non-visible disabilities such as a learning disability, an attention deficit disorder, or a mental health issue can face difficulties such as handling time pressure, maintaining attention to task, interacting with others, being uncomfortable with changes, keeping energy level up, approaching authority figures, processing information, reading, coping with stress, etc. It is important to note that, some teachers do not know that there are minor impairments that learners have which warrant their attention during teaching. This means that teachers do not think about such learners while preparing their lessons, selecting instructional material and teaching. Such category of learners are excluded, abandoned, stigmatised, frustrated and do not feel a sense of belonging in class. We want to believe that such learners are those who manifest their frustration in class through various ways like being violent, sleeping, making noise and moving in and out of class, playing with their phones and using hate language while teaching is going on. They are learners who do not feel like members of the class community.

\subsection{The Role of Inclusive Teaching Practices}

ITP leads to more understanding, better performance and more satisfied students (Vukovic, 
2012, 2010; Burgstahler \& Cory, 2008). Questions 15 and16 of part two of the questionnaire investigated from instructors if ITP and humanistic teaching practices can enhance teaching and all instructors in all the three schools unanimously answered Yes. Their reaction confirms the findings of previous researchers. ITP create a sense of belonging, a conducive learning scene and enhances learners' participation.

Similarly, questions 17-18 of part two of the questionnaire looked into instructors' opinion whether inclusive humanistic practices can minimize violence in English language classes which all collectively affirmed. Their opinion tie in with Crenshaw \& Mordock (2005), Hoffman (2000), O'Ferrall, Green \& Hanna (2010) and Rogers (1983) who attest that clients-centred teaching practice led to fewer acts of vandalism. We are equally of the opinion that inclusive humanistic teaching practices will minimize negative feedbacks from instructors and students, inappropriate correction approaches by instructors and hate speech from instructors thereby calming down tension and frustration that might result to violence in the classroom.

\subsection{Inclusive Classroom Practices by English Language Instructors}

Many researchers (Vukovic, 2012; Lombardi \& Murray, 2011; Milligan, 2010) hold that ITP is also embracing a reflective practice and a welcoming attitude, in addition to varying teaching methods, to provide all students with engaging, challenging and relevant learning activities in a cognitively, emotionally and physically safe and barrier free environment. Also, ITP for others (Shaw, 2011; Barkley, 2010; Bowman, 2010; Cameron 2010/1999; Edyburn, 2010; Shaw, 2010, 2011; Gross-Davis, 2009; McGuire \& all, 2006; Moses \& Chang, 2006; Hatfield, 2003) supports the current change in roles for educators, from information provider (e.g. lecturing) to guide and facilitator to learning (e.g. active learning). Inclusive behaviours by instructors while teaching, whether cognitive or affective; help language teachers to move on together with all their learners in peaceful co-existence during their language lessons. It makes learners to feel a sense of belonging to a class community and makes teaching inclusive and participative. There are several practices that language teachers can adopt for greater achievement of inclusiveness in teaching, for the creation of a convivial learning environment and for the enhancement of learning. Part three of the instructors' questionnaire investigated inclusive behaviour by language instructors as they were asked to scale their classroom inclusive practices from 5-1 representing always, usually, sometimes, seldom and never respectively. The practices had to do with the following: Carrying out regular diagnosis to know learners and to remember the different types of learners when planning lessons, designing materials and giving tasks; varying method, material, task, example and assessment to suit learners with deficit; preparing alternative material, task, example and assessment to accommodate learners with deficit; giving more time and attention to impaired learners; encouraging cooperative learning through mix ability groupings and building language communities in the classroom.

This section of the questionnaire constituted 24 inclusive classroom behaviour and instructors had to scale their rate of implementing these practices in their classes. The results were calculated per scale and reported below. 


\section{Macrothink}

Table 6. Inclusive classroom practices by instructors

\begin{tabular}{|l|l|l|l|l|l|l|}
\hline $\begin{array}{l}\text { Teachers use of } \\
\text { empathic } \\
\text { behaviour in class }\end{array}$ & Total & $\begin{array}{l}5 . \\
\text { Always }\end{array}$ & $\begin{array}{l}4 . \\
\text { Usually }\end{array}$ & $\begin{array}{l}3 . \\
\text { Sometimes }\end{array}$ & 2. Seldom & 1. Never \\
\hline GBHS Bafang & 192 & 24 & 29 & 35 & 48 & 56 \\
\hline GBHS Bamenda & 192 & 50 & 27 & 30 & 51 & 34 \\
\hline GTHS Maroua & 240 & 30 & 15 & 39 & 45 & 112 \\
\hline Total & 624 & 104 & 71 & 104 & 144 & 202 \\
\hline Percentages & $100 \%$ & $16.67 \%$ & $11.38 \%$ & $16.67 \%$ & $23.08 \%$ & $32.38 \%$ \\
\hline
\end{tabular}

To get the total number of responses per school is the number of informants multiplied by the number of questions (24) making a total of 192 each for Bafang and Bamenda, 240 for Maroua giving a total of 624 . To better appreciate the situation, responses that had to do with always and usually were grouped as one, Sometimes was left alone while seldom and never were equally grouped as one and pictured in figure 2 below.

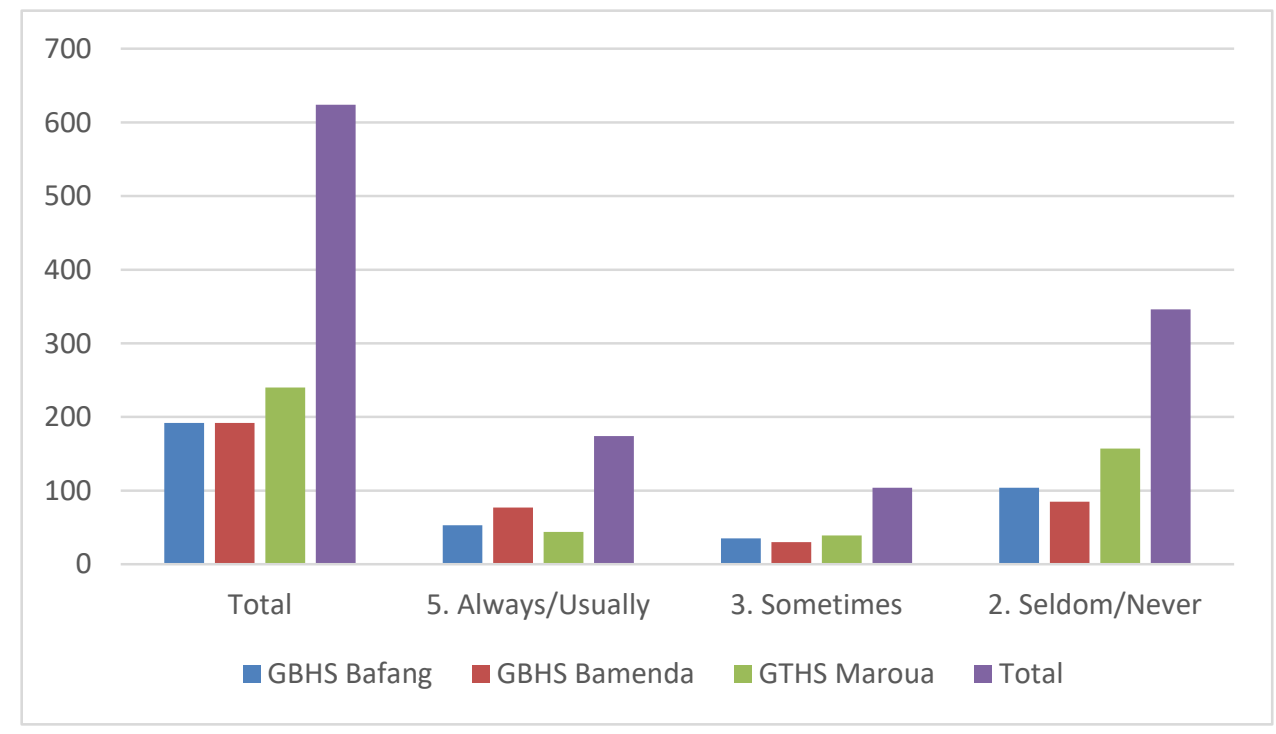

Figure 2. Scale of ITP in class.

Notice that, a very high percentage $(55.46 \%)$ of teachers never/seldom adopt ITP during their language classes while only $16.67 \%$ sometimes/barely while only $28.05 \%$ always/usually take up inclusive attitudes towards their learners during their language classes. The fact that a very high percentage of teachers never adopt ITP presupposes that teacher-centered approaches are still widely used and target the 'average' student. Such approaches do not work well with diverse students learning needs (Subban, 2006). Failure by instructors to show inclusive cognitive and affective concern to learners during language teaching is a pointer to the fact that many students will acquire very little knowledge and thus feel lonely, excluded and 
frustrated in class. Such feelings nurtures hatred and can lead to violence when it comes from learners with mental deficits. This finding collaborates with that of Anapiosyan, Hayrapetyan \& Hovsepyan (2014) who hold that $90 \%$ of teachers lacked teaching methodologies that would effectively include children with disabilities in class activities thereby leading to either poor quality inclusion or even exclusion.

\section{Conclusion}

This paper that sets out to investigate ITP by ELI and its role in minimizing violence and enhancing teaching confirms its hypotheses and came out with some findings which are implicational to policy, teaching practice and research .

Findings reveal that most ELI have never participated in workshops or career development courses on special needs education, inclusive teaching and differentiation and so, have not acquire the competence needed in inclusive teaching. These findings incriminates the ministries of Education who should have a policy of organizing workshops or career development courses for instructors in the field based on special needs education, inclusive education and differentiation for them to acquire skills of teaching that are inclusive, humanistic and holistic. The above finding further incriminates teachers training colleges who are advised to expand their pedagogic course content to include issues on Special Needs Education, ITP and differentiation to facilitate inclusive teaching and appropriate classroom management practices in the field.

Further results show that majority of ELI hardly adopt ITP and consequently, most of them do not think about all the category of students they have in class, do not try to wear the shoes of all category of students by applying inclusive humanistic and holistic teaching practices during class thereby excluding learners with deficits from the teaching/learning process. Another finding depicts that failure to use ITP creates tension, frustration, isolation, humiliation, no sense of belonging for students and such environment breathes hatred, hate speech and violence. These implicate ELI who should strive to know more on the subject matter and adopt classroom behaviours that are in line with them.

Small changes by ELI can make a huge difference in the classroom situation. So, instructors should start by redesigning their whole course structure, making small revisions based on ITP principles within the context of their own course content and teaching styles (Burgstahler \& Cory, 2008:150). Instructors may start from their current practices and add a few changes at a time, respecting their own pace, with the resources at their disposal. Organizing teaching to vary the ways that the material is conveyed optimizes student learning. They should adopt inclusive classroom practices while teaching to render teaching holistic and humanistic. Diverse inclusive teaching strategies should be used at the classroom level by ELI to address the needs of diverse learners such as Peer-assisted learning strategies (PALS) propounded by McMaster, Fuchs, and Fuchs (2006), Cooperative learning (Mkrtchyan, 2012) and direct instruction developed by Engelmann and Becker (1977) cited by Renáta et al. The above finding implicates teachers who act as school administrators more especially, discipline 
masters/mistresses who should be tactful when dealing with students.

The outcomes from this study are not only implicational to policy decision on English Language Teaching in Cameroon as seen above. It entangles classroom based researcher. While reading literature on the topic, I found out that there is a gap in research on ITP by teachers in Cameroon and thus, this study will open the way for further research on this area which seems underexploited by researchers on classroom based research. Given that classroom-based research on Special Needs Education and inclusive teaching are under exploited by researchers in Cameroon, it will be interesting if other disciplines carryout research on ITP and its pedagogic implication. Given that it is common today in Cameroon to hear that a student has stab a teacher in the classroom, further research can be done on inclusive teaching and peace negotiation in the language classroom. Further finding revealed that a handful of ELI never adopt ITP in class and thus exclude learners with deficits during teaching. In consonance with these, teachers' cognitive memory and its role in creating classroom community can equally be investigated. Since further finding shows that most teachers in Cameroon are not trained on Special Needs Education, and inclusive teaching, it can be vital for another study to be carried out on inclusive teaching and its impact on classroom participation.

It is hoped that the findings, recommendations and the conclusions arrived at in this study will help in the enhancement of ELI classroom practices for the enhancement of learning and minimization of violence. More importantly, the findings will hopefully push further research actions and enhance policy decision on English language teachers' training in Cameroon.

\section{Acknowledgement}

The research is financed by the authors. We are thankful to English Language Instructors from GBHS Bafang, GBHS Bamenda and GTHS Maroua for filling in the questionnaire designed for this study.

\section{References}

Ainscow, M., Booth T., \& Dyson, A. (2006). Inclusion and the standards agenda: Negotiating policy pressures in England. International Journal of Inclusive Education, 10(4-5), 295-308. https://doi.org/10.1080/13603110500430633

Anapiosyan, A., Hayrapetyan, G., \& Hovsepyan, S. (2014). Approximation of inclusive education in Armenia to international standards and practices. Yerevan, Armenia: Open Society Foundations-Armenia Policy Fellowship Initiative.

Bailleul, P., Bataille, A., Langlois, C., Lanoe, P. \& Mazereau, P. (2008). From disabled pupils' integration to inclusive schooling: current situation and new teacher training needs. Shedding light on the European situation accessed from http://www.unicaen.fr/recherche/mrsh/files/Rapport.SEH_.pdf (22.10.2016).

Barkley, E. (2010). Student Engagement Techniques, A Handook for College Faculty. San Francisco, CA: Jossey-Bass Publishers. 
Beaudoin, J. (2013). Introduction to Inclusive Teaching Practices. 10, Centre for University Teaching, University of Ottawa.

Belch, H. (2004). Retention and students with disabilities. Journal of College Student Retention, 6, 3-22. https://doi.org/10.2190/MC5A-DHRV-1GHM-N0CD.

Belch, H. A. (2011). Understanding the experiences of students with psychiatric disabilities: A foundation for creating conditions of support and success. New Directions for Student Services, 134, 73-94. https://doi.org/10.1002/ss 396

Bowman, N. A. (2010). College Diversity Experiences and Cognitive Development: A Meta-Analysis. Review of Educational Research, 80(1), 4-33. https://doi.org/10.1002/ss 396

Burgstahler, S., \& Cory, R. (2008). Universal design in higher education: from principles to practice. Cambridge, MA: Harvard Press. https://doi.org/10.1080/09362830802412216

Burgstahler, S., \& Doe, T. (2006). Improving postsecondary outcomes for students with disabilities: Designing professional development for faculty. Journal of Postsecondary Education and Disability, 18(2), 135-147.

Cameron, B. J. (1999, reprinted 2010). Active Learning, Green Guide \#2. London, ON: Society for Teaching and Learning in Higher Education (STLHE).

Cardona, M. M. (2009). Teacher education students' beliefs of inclusion and perceived competence to teach students with disabilities in Spain. International journal of Special Education, 10, 33-41.

Carroll, A., Forlin, C., \& Jobling, A. (2003). The impact of teacher training in special education on the attitudes of Australian preservice general educators towards people with disabilities. Teacher Education $\quad$ Quarterly, 30, https://doi.org/10.1111/j.0952-3383.2003.00307

Crenshaw, D. A. \& Mordock, J. B. (2005). Understanding and treating the aggression of children. U.S.A.: Jason Aronson

Devlin, M., Kift, S. Nelson, K., Smith, L., \& McKay, J. (2012). Effective teaching and support of students from low socioeconomic status backgrounds: Practical advice for institutional policy makers and leaders. Sydney: Office of Learning and Teaching.

Denhart, H. (2008). Perceptions of students labeled with learning disabilities in higher education. Journal of Learning Disabilities, 41, 483-497.

Edyburn, D. L. (2010). Would you recognize universal design for learning if you saw it? Ten propositions for new directions for the second decade of UDL. Learning Disability Quarterly, 33(1), 33-41.

Engelmann, S., Becker, W., Haner, S., \& Johnson, G. (1979). Corrective reading. Chicago: Science Research Associates. 


\section{Al Macrothink}

International Journal of English Language Education

ISSN 2325-0887

2020, Vol. 8, No. 2

Florian, L., \& Rouse, M. (2009). The inclusive practice project in Scotland: Teacher education for inclusive education. Teaching and Teacher Education, 25(4), 594-601. https://doi.org/10.1016/j.tate.2009.02.003.

Fuller, M., Bradley, A., \& Healey, M. (2004). Incorporating disabled students within an inclusive higher education environment. Disability \& Society, 19(5), 455-468.

Gross-Davis, B. (2009). Tools for Teaching, 2nd edition, San Francisco, CA: Jossey-Bass Publishers.

Hockings, C. (2010). Inclusive learning and teaching in higher education: A synthesis of research. York: Higher Education Academy.

Hoffman, M. L. (2000). Empathy and moral development: implications for caring and justice. Cambridge: Cambridge University Press.

Hatfield, J. P. (2003). Perception of Universal (Instructional) Design: A qualitative examination. In J. L. Higbee (Ed.), Curriculum transformation and disability: Implementing Universal Design in higher education (pp. 41-58). Minneapolis: University of Minnesota, General College, Center for Research on Developmental Education and Urban Literacy.

Hindes, Y., \& Mather, J. (2007). Inclusive education at the post-secondary level: Attitudes of students and professors. Exceptionality Education Canada, 17(1), 107-127.

Lehmann, J. P., Davies, T. G., \& Laurin, K. M. (2000). Listening to student voices about postsecondary education. Teaching Exceptional Children, 32(5), 60-65.

Lombardi, A. R. Murray, C. (2011). Measuring university faculty attitudes toward disability: Willingness to accommodate and adopt Universal Design principles. Journal of Vocational Rehabilitation, 34, 43-56.

Ladson-Billings, G. (2014). Culturally relevant pedagogy 2.0: a.k.a. the remix. Harvard Educational Review, 84(1), 74-84. https://doi.org/10.17763/haer.84.1.p2rj131485484751

McGuire, J. M., Sally S. \& Shaw, S. F. (2006). Universal Design and Its Applications in Educational Environments. Remedial and Special Education, 27(3), 166-175. https://doi.org/10.1177

McMaster, K. L., Fuchs, D., \& Fuchs, L. S. (2006). Research on peer-assisted learning strategies: The promise and limitations of peer-mediated instruction. Reading \& Writing Quarterly, 22(1), 5-25.

Milligan, N. V. (2010). The effects of training about academic accommodations on perceptions and intentions of health science faculty. Journal of Allied Health, 39, 54-61.

Mkrtchyan, M. (2012). The methodology, theory and practice of realizing collective organizing instruction. (Thesis for degree of doctor of pedagogical sciences; specialty, theory and history of pedagogy). Yerevan: Armenia.

Moses, M. S., \& Chang, M. J. (2006). Toward a Deeper Understanding of the Diversity 
Rationale. Educational Researcher, 35(1), 6-11.

O'Ferrall, M. E., Green, A. \& Hanna, F. (March, 2010). Classroom management strategies for difficult students: promoting change through relationships. Middle School Journal, 41(4), 4-11.

Ouellett, M. L. (2004). Faculty Development and Universal Instructional Design. Equity \& Excellence in Education, 37, 135-144.

Renáta, T., Brian H. A., Christopher J., Alvard P., \& Paula F. H. (ed)(2018). Inclusive Education strategies: A Textbook. University of Minnesoto, USA.

Sanders, W., Wright, L., \& Horn, S. (1997). Teacher and classroom context effects on student achievement: implications for teacher evaluation. Journal of Personnel Evaluation in Education, 11(1), 57-67. https://doi.org/10.1023/A:1007999204543

Savolainen, H. (2009). Responding to diversity and striving for excellence: The case of Finland. Prospects, 39, 281-292.

Shaw, J. (2010). The diversity paradox: does student diversity enhance or challenge excellence? Journal of Further and Higher Education, 33, 4, 321-331.

Rogers, C. (1983). Freedom to learn for the 80s. Columbus, OH: Charles E. Merrill Company.

Shaw, R. (2011). Employing Universal Design for Instruction. New Directions for Student Services, 134, 73-94.

Subban, P. (2006). Differentiate instruction: A research basis. International Education Journal, 7(7), 935-947. https://doi.org/10.1080/1359866X.2013.777326

The United Nations. (2006). Convention on the Rights of Persons with Disabilities. Treaty Series, 2515, 3.

Tomlinson, C. A. (2004). Sharing responsibility for differentiating instruction. Roeper Review, 26(4), 188-200.

Tomlinson, C. A. (2005). Grading and differentiation Paradox or good practice? Theory into Practice, 44(3), 262-269.

UNESCO. (2005). Guidelines for inclusion: Ensuring access to education for all. Paris, France. Retrieved from http://www.ibe.unesco.org/sites/default/files/Guidlines_for_Inclusion_UNESCO_2006.pdf UNICEF. (2017). Inclusive education: Understanding Article 24 of the Rights of Persons with Disabilities. Geneva, Switzerland: UNICEF Regional Office for Europe and Central Asia. Retrieved from https://www.unicef.org/eca/sites/unicef.org.eca/files/IE_summary_acessible_220917_0.pdf

Vukovik, B. (2012). Promoting Accessible Learning Environments: Faculty Disability Awareness and Development in Higher Education. Unpublished. 
Weyandt, L. L., \& DuPaul, G. J. (2006). ADHD in College Students: A review of the literature. Journal of Attention Disorders, 10, 9-19.

Wolf, L., Schreiber, H. E., \& Wasserstein J. (2008). Adult learning disorders: contemporary issues. New York: Taylor \& Francis. https://doi.org/10.1016/S08876177(01)00177-9 PMID:14591474

\section{Appendix}

Appendix 1. Instructors' Questionnaire

Dear Respondent:

This questionnaire is prepared to illicit data for an enquiry on 'Inclusive Teaching Practices. Specifically it is intended to study how English language instructors include all learners while teaching through the use of certain strategies.

The genuine responses provided in this questionnaire are confidential, it will be used only for research purpose and it will contribute a lot to the successful completion of this study. You do not need to write your name.

Thank you very much for your cooperation.

PART ONE: Please put a tick mark in the appropriate box which represents your response and by writing the necessary information.

1. Sex: Male Female

2. Current academic status: DIPES, B.A., above B.A., A.L., below A.L.

3. Secondary school affiliated to:

4. How many classes do you teach currently?

5. Number of students in one class (average)....

PART TWO: Please put a tick mark in the appropriate option which represents your response.

\begin{tabular}{|l|l|c|c|}
\hline No. & Questions & Yes & NO \\
\hline 1 & Have you got any training in Special Needs Education? & Yes & NO \\
\hline 2 & Have you got any training in Inclusive education before? & Yes & NO \\
\hline 3 & Have you got any training on differentiation before? & Yes & NO \\
\hline 4 & To be impaired means to be disabled. & Yes & NO \\
\hline 5 & To be impaired means to be rendered less effective. & Yes & NO \\
\hline 6 & Have you taught impaired students before? & Yes & NO \\
\hline 7 & $\begin{array}{l}\text { Have you ever taught in a class where you have some students with } \\
\text { sight deficit? }\end{array}$ & Yes & NO \\
\hline 8 & $\begin{array}{l}\text { Have you ever taught in a class where you have some students with } \\
\text { hearing deficit? }\end{array}$ & Yes & NO \\
\hline 9 & Have you ever taught in a class where you have some students with & Yes & NO \\
\hline
\end{tabular}




\section{Ml Macrothink}

\begin{tabular}{|c|c|c|c|}
\hline & reading deficit? & & \\
\hline 10 & $\begin{array}{l}\text { Have you ever taught in a class where you have some students with } \\
\text { speech deficit? }\end{array}$ & Yes & $\mathrm{NO}$ \\
\hline 11 & $\begin{array}{l}\text { Have you ever taught in a class where you have some students with } \\
\text { action deficit? }\end{array}$ & Yes & $\mathrm{NO}$ \\
\hline 12 & $\begin{array}{l}\text { Have you ever taught in a class where you have students } \\
\text { understanding deficit? }\end{array}$ & Yes & $\mathrm{NO}$ \\
\hline 13 & $\begin{array}{l}\text { Have you ever taught in a class where you have some students with } \\
\text { attention deficit? }\end{array}$ & Yes & $\mathrm{NO}$ \\
\hline 14 & $\begin{array}{l}\text { Have you ever taught in a class where you have some students with } \\
\text { participation deficit? }\end{array}$ & Yes & $\mathrm{NO}$ \\
\hline 15 & $\begin{array}{l}\text { Do you think that inclusive classroom practices by instructors can } \\
\text { minimize violence of teachers by students? }\end{array}$ & Yes & NO \\
\hline 16 & $\begin{array}{l}\text { Do you think that being humanistic to students can minimize } \\
\text { violence in the classroom? }\end{array}$ & Yes & $\mathrm{NO}$ \\
\hline 17 & $\begin{array}{l}\text { Do you think that inclusive classroom practices by instructors can } \\
\text { enhance learning? }\end{array}$ & Yes & NO \\
\hline 18 & $\begin{array}{l}\text { Do you think that being humanistic to students can enhance } \\
\text { learning? }\end{array}$ & Yes & $\mathrm{NO}$ \\
\hline
\end{tabular}

\section{PART THREE}

For each of the statements below, please indicate the extent of your agreement or disagreement by putting a tick mark in the most appropriate answer box. Your choice should be based on your actual practices and experiences of teaching English at the moment.

The response scale is as follows:
5.Always
4.Usually
3. Sometimes
2.Seldom
1.Never

\begin{tabular}{|l|l|l|l|l|l|l|}
\hline No. & $\begin{array}{l}\text { Statements( practice) } \\
\text { Scale }\end{array}$ & 5 & 4 & 3 & 2 & 1 \\
\hline 1 & $\begin{array}{l}\text { When I prepare a lesson plan, I consider the needs of impaired students } \\
\text { in my class. }\end{array}$ & 5 & 4 & 3 & 2 & 1 \\
\hline 2 & $\begin{array}{l}\text { When I teach I always consider the presence of impaired students in } \\
\text { class. }\end{array}$ & 5 & 4 & 3 & 2 & 1 \\
\hline 3 & $\begin{array}{l}\text { I give available materials to impaired students to make them perform } \\
\text { equally with other students. }\end{array}$ & 5 & 4 & 3 & 2 & 1 \\
\hline 4 & $\begin{array}{l}\text { I carry out regular diagnosis of students in my class in order to plan on } \\
\text { how to give them concern during my classes. }\end{array}$ & 5 & 4 & 3 & 2 & 1 \\
\hline 5 & I devote more of my time to support impaired students. & 5 & 4 & 3 & 2 & 1 \\
\hline 6 & I closely follow-up the participation of impaired students in class. & 5 & 4 & 3 & 2 & 1 \\
\hline 7 & I regularly assess impaired students differently during my classes & 5 & 4 & 3 & 2 & 1 \\
\hline 8 & $\begin{array}{l}\text { I vary teaching material to accommodate impaired students' needs. For } \\
\text { example using written descriptions instead of pictures. }\end{array}$ & 4 & 3 & 2 & 1 \\
\hline
\end{tabular}




\begin{tabular}{|l|l|l|l|l|l|l|}
\hline 9 & I vary assignments based on the category of learners I have in class & 5 & 4 & 3 & 2 & 1 \\
\hline 10 & $\begin{array}{l}\text { I communicate with parents and concerned bodies about the progress of } \\
\text { students. }\end{array}$ & 5 & 4 & 3 & 2 & 1 \\
\hline 11 & $\begin{array}{l}\text { I encourage cooperative learning through pair/group exercises to make } \\
\text { all students support each other. }\end{array}$ & 5 & 4 & 3 & 2 & 1 \\
\hline 12 & I allow low vision students to sit in front. & 5 & 4 & 3 & 2 & 1 \\
\hline 13 & I use large font while writing on the chalkboard. & 5 & 4 & 3 & 2 & 1 \\
\hline 14 & $\begin{array}{l}\text { I assign sighted students to help visually impaired students do different } \\
\text { activities in class. }\end{array}$ & 5 & 4 & 3 & 2 & 1 \\
\hline 15 & $\begin{array}{l}\text { I prepare alternative assignments/ activities to make impaired students } \\
\text { work better. }\end{array}$ & 5 & 4 & 3 & 2 & 1 \\
\hline 16 & $\begin{array}{l}\text { I prepare alternative assessments/exams taking into consideration } \\
\text { impaired students. }\end{array}$ & 5 & 4 & 3 & 2 & 1 \\
\hline 17 & I read what I have written on the board while teaching. & 5 & 4 & 3 & 2 & 1 \\
\hline 18 & $\begin{array}{l}\text { I adopt suitable methods that reach out to learners with different } \\
\text { disabilities. }\end{array}$ & 5 & 4 & 3 & 2 & 1 \\
\hline 19 & $\begin{array}{l}\text { I make sure that there is an atmosphere free of stigma and discrimination } \\
\text { in my class. }\end{array}$ & 5 & 4 & 3 & 2 & 1 \\
\hline 20 & I use multi sensory approach while teaching. & 5 & 4 & 3 & 2 & 1 \\
\hline 21 & $\begin{array}{l}\text { I use different concrete examples to facilitate the way impaired students } \\
\text { understand the concept. }\end{array}$ & 5 & 4 & 3 & 2 & 1 \\
\hline 22 & I build language classroom community from my first day in class. & 5 & 4 & 3 & 2 & 1 \\
\hline 23 & I take time to know my students on a personal level. & 5 & 4 & 3 & 2 & 1 \\
\hline 24 & I build trust with my students in my classroom. & 4 & 3 & 2 & 1 \\
\hline
\end{tabular}

\section{Copyright Disclaimer}

Copyright for this article is retained by the author(s), with first publication rights granted to the journal.

This is an open-access article distributed under the terms and conditions of the Creative Commons Attribution license (http://creativecommons.org/licenses/by/3.0/). 